Article

\title{
New Approach Evaluating Peatland Fires in Indonesian Factors
}

\author{
Hiroshi Hayasaka ${ }^{1, *}$, Aswin Usup ${ }^{2}$ and Daisuke Naito ${ }^{3,4}$ \\ 1 Arctic Research Center, Hokkaido University, Sapporo 0010021, Japan \\ 2 Research Center for Fire Prevention and Land Rehabilitation, Palangka Raya University, \\ Palangka Raya City 74874, Central Kalimantan, Indonesia; aswin@agr.upr.ac.id \\ 3 Center for International Forestry Research (CIFOR), Bogor 16115, Indonesia; D.Naito@cgiar.org \\ 4 Faculty/Graduate School of Agriculture, Kyoto 6068502, Japan \\ * Correspondence: hhaya@eng.hokudai.ac.jp
}

Received: 6 May 2020; Accepted: 25 June 2020; Published: 26 June 2020

check for updates

\begin{abstract}
Until 2018, the El Niño-Southern Oscillation (ENSO) was used as an explanation for fires in Indonesia's peatlands. However, when the 2019 fires occurred independently of El Niño, more suitable indicators and methods were required to (a) analyze, (b) evaluate and (c) forecast peatland fires. In this study, we introduced the OLR-MC index-one of the rain-related indices derived from OLR (outgoing longwave radiation) in MC (maritime continent) area in Indonesia. This index showed stronger correlation with active peatland fires than the conventional ENSO index, and is likely to be able to respond to heat and dry weather supposed to be under climate-change conditions. We then analyzed peatland fires in the top six fire years from 2002 to 2018 and showed that peatland fires occurred in three stages-surface fire, shallow peatland fire and deep peatland fire. To explain each stage, we proposed a one-dimensional groundwater level (GWL) prediction model (named as MODEL-0). MODEL-0 predicts GWL from daily rainfall. Analysis using MODEL-0 showed the GWL thresholds for the three fire stages were between $-300 \mathrm{~mm}$ and $-500 \mathrm{~mm}$; peatland fire activities during the three fire stages were dependent on these GWL values. The validity of MODEL-0 was shown by comparison with the measured values of GWL in the top three fire years.
\end{abstract}

Keywords: peatland fire; OLR; ENSO; rainfall; drought; MRP; groundwater level

\section{Introduction}

Indonesia has some of the world's highest rates of deforestation and forest degradation, the principle drivers of which are agricultural expansion and wood extraction in combination with an increased incidence of fire [1]. An average annual clearance rate of $10 \times 10^{3} \mathrm{~km}^{2}$ during the $1980 \mathrm{~s}$ has increased to an average of $20 \times 10^{3} \mathrm{~km}^{2}$ per year since 1996. The largest tree-cover loss since 2001 was $24.2 \times 10^{3} \mathrm{~km}^{2}$ in 2016 [2].

As fire has been employed as a cheap land-clearance tool, uncontrolled fires from various sources have entered adjacent forests or plantation estates, and burnt both the forest biomass and, in peatland areas, underlying peat [1]. Analysis of recent land-cover change has underscored the close link between land management and fire activity [3]. Most burn scars were located along forest edges (i.e., disturbed forest), usually in close proximity to human settlements that provided a source of ignition. More remote, intact forests were unaffected by fire, even during extended El Niño-Southern Oscillation (ENSO) drought [1].

ENSO events or droughts also play a role in exacerbating fire occurrence and severity [1]. The worst fires were associated with strong ENSO episodes, including the fires of 1972-73, 1982-83 (the 'Great Fire of Borneo'), 1994, 1997-98, 2002 and 2006. The 1982-83 fires were estimated to have burnt $32 \times 10^{3} \mathrm{~km}^{2}$, 
of which $27 \times 10^{3} \mathrm{~km}^{2}$ was forest [4], including $5.5 \times 10^{3} \mathrm{~km}^{2}$ of peat swamp [5]. The area affected by the 1997-98 fires (due to a very strong El Niño) was estimated at about $97 \times 10^{3} \mathrm{~km}^{2}$ [6]. Under very strong El Niño conditions in 2015, the burnt area was about $26 \times 10^{3} \mathrm{~km}^{2}$ [7]. Active peatland fires in 2019 occurred despite the ENSO indices being neutral and burnt about $16 \times 10^{3} \mathrm{~km}^{2}$ [8]. This suggests we have to consider the impact of recent climate change on fires in Indonesia. The fire history is summarized in Table 1. Niño 3.4 is one of the ENSO indices. The OLR-MC is a rain-related index derived from outgoing longwave radiation (OLR) issued by Japan Meteorological agency (JMA). There are two papers showing that correlation between OLR and rainfall in tropical regions $[9,10]$.

Table 1. Fire years under El Niño.

\begin{tabular}{ccc}
\hline Year & Niño 3.4 & OLR-MC $^{\mathbf{1}}$ \\
\hline $1972-73$ & 2.17 & none \\
$1982-83$ & 2.09 & -2.3 \\
1994 & 1.19 & -0.8 \\
$1997-98$ & 2.48 & -1.8 \\
2002 & 1.41 & -0.7 \\
2006 & 1.09 & -1.9 \\
2015 & 2.67 & -1.1 \\
2019 & 0.48 & -1.9 \\
\hline
\end{tabular}

The risk of fire on peatland is increased greatly by drainage, which lowers the water table, exposing a greater volume of dry peat to combustion. This effect is demonstrated by a study of the fire regime in the former mega rice project (MRP) area on peatland in southern Central Kalimantan [11]. From 1973 to 1996 , fires affected $24 \%$ of a $4.5 \times 10^{3}-\mathrm{km}^{2}$ Block C area in MRP. Following multiple fires in peat swamp forest, the numbers of tree species and individual trees, saplings and seedlings within the secondary vegetation are greatly reduced and, at the highest levels of degradation, succession back to forest is diverted to a retrogressive succession to communities dominated by ferns with very few or no trees [12,13]. Non-forested areas in Kalimantan had shorter average fire return intervals (FRI) than Sumatra (13 years versus 40 years), with ferns/low shrub areas burning most frequently [14].

Peatland fires make a major contribution to emissions of greenhouse gases, fine particulate matter and aerosols, thus contributing to climate change as well as presenting a problem for human health [1]. The devastating 1997-1998 Indonesian fires were among the largest peak emission events in the recorded history of fires in equatorial Southeast Asia $[15,16]$. According to a recent report on intense fires in 2015, peat fires in Indonesia during July-October 2015 released about $2 \mathrm{Tg}$ of carbon into the atmosphere, $81 \%$ of which was in the form of carbon dioxide $\left(\mathrm{CO}_{2}\right) ; 16 \%$ carbon monoxide $(\mathrm{CO})$ and 2.3\% methane $\left(\mathrm{CH}_{4}\right)$ [17]. Fine particulate matter (PM2.5) emissions from fires across Sumatra and Kalimantan (Borneo) during September-October 2015 were estimated at $7.33 \mathrm{Tg}$ [18]. The level of major air-pollution gases and particulate matter (PM10) at Palangkaraya near the mega rice project was already reported [19].

Smoldering wildfire in peatlands is one of the largest and longest-lasting fire phenomena on Earth [20]. Losses of carbon from above-ground biomass (AGB) usually greatly exceed those from soil, but in regions with carbon-rich substrates-e.g., peat swamp forests-combustion losses from below-ground stocks can be much greater than AGB losses [1]. For this reason, much peat research is carried out to control fires in peatland and to clarify the background conditions of multiple fires in peatland.

Comprehensive peat study clarified the combustion properties of peat, the thermal characteristics of peat fire, the temperature distribution in peat layers during fire, the pattern of peat fire fronts and the peat fire spreading speed [21]. 
Experiments on smoldering and flaming conditions of peat demonstrated the successful piloted flaming ignition of peat soil with moisture up to $100 \mathrm{wt} \%$ under external radiation, indicating that flames may spread rapidly on peatland before transitioning to a conventional smoldering peat fire [20].

The upward and downward spread of smoldering peat fire was analyzed using a one-dimensional computational model. Results showed that smoldering combustion can spread over peat layers with very high moisture content (MC) (MC > 250\%) if the layer is thin and located below a thick, drier layer [22].

In this study, we discuss two issues related to peatland fires in Indonesia. First, we introduce one of existing indicators to explain active fires in 2019 occurred regardless of ENSO-neutral. The correlation between the OLR-MC and the fire occurrence is analyzed. The OLR-MC is one of indices issued by JMA and a rain-related index derived from outgoing longwave radiation (OLR) in Indonesia (MC: maritime continent, area from Kalimantan to west Papua).

Second, we propose a one-dimensional groundwater level (GWL) prediction model (MODEL-0) to evaluate peat fire activities. MODEL-0 needs daily rainfall as input data to calculate the diurnal change of GWL. Therefore, rainfall data from satellite observations, meteorological observatory data and estimated values from OLR are compared.

Finally, we analyze peatland fire activities during the top six fire years from 2002 to 2018 to find their active fire periods. To explain fire activities during the fire stages, we used MODEL-0 to identify the relationship with GWL.

\section{Study Area and Data}

\subsection{Study Area}

Figure 1 shows the peatland distribution and study area in Kalimantan (Borneo). Palangkaraya is the capital of Central Kalimantan is located in the southern part of the province $\left(2.21^{\circ} \mathrm{S}\right.$, $113.92^{\circ} \mathrm{E}$ - hereafter, a simpler expression without the degree sign will be used, e.g., 2.21-2.23 S). Peatlands in Kalimantan cover about $57,600 \mathrm{~km}^{2}$ and are equivalent in area to that of Sumatra. Central Kalimantan alone has $30,100 \mathrm{~km}^{2}$ of peatlands. The distance from the nearest coastline is about $100 \mathrm{~km}$ and the average altitude is only around $10 \mathrm{~m}$. The MRP was built on tropical swamp forest areas on the eastern and southern sides of Palangkaraya. Before the disturbance, the tropical swamp forest could hold enough water to stay wet even in the dry season. However, the newly constructed 4000-km-long MRP canal built for irrigation facilitated not only illegal logging, but also a loss of water through drainage from most of the peatlands in the MRP area. These disturbances are the main reasons for intense and recurrent fire activity in the MRP area.

We refer to the study area as 'MRP+' in this report. MRP+ covers the MRP area and its vicinity (a part of the Sebangau National Park) (1.75-3.5 S, 113.5-115.0 E). MRP is divided into five blocks: Block A to Block E, as shown in Figure 1. Their actual boundaries are defined mainly by rivers. In this report, approximate boundaries defined by latitude and longitude lines are used for convenience. MRP+ was chosen as the study area simply because MRP+ area has major peatland in Central Kalimantan and is one of the highest hotspot density areas in Indonesia [23]. 


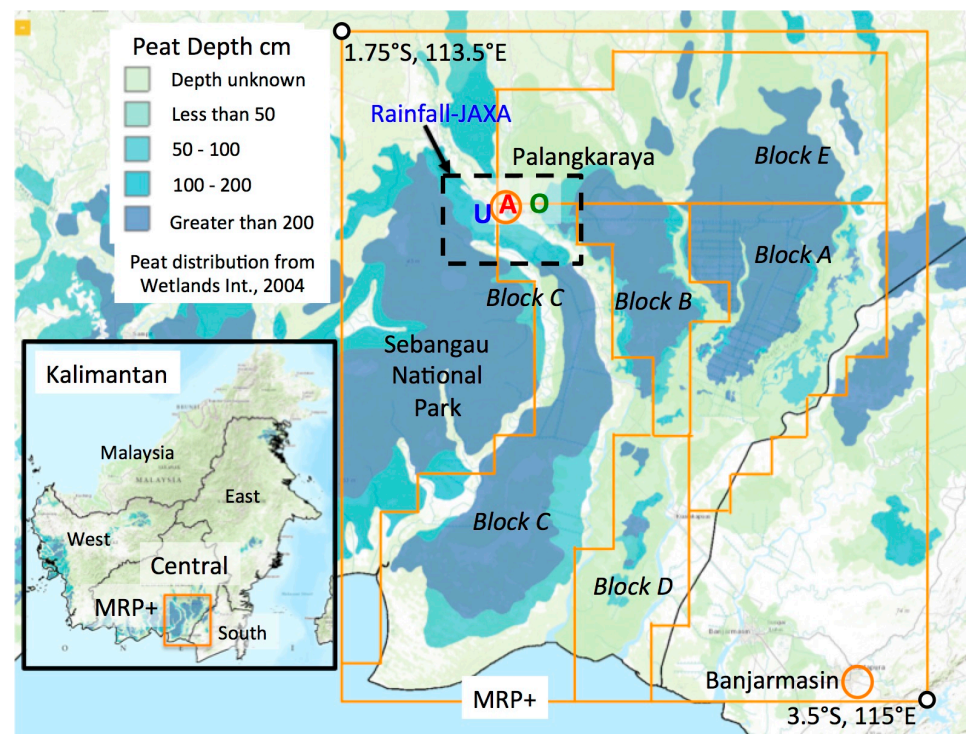

Figure 1. Study area, MRP+ and Kalimantan. mega rice project (MRP)+ cover area: 1.75-3.5 S, 113.5-115 E; A: Tjilik Riwut Meteorology Station (TRMS) (2.226 S, 113.95 E); U: groundwater level (GWL) measured site (2.32 S, 113.9 E); O: OLR reference point (2.21 S, 114 E); dotted line rectangle: reference area for JAXA rainfall; base peat depth map: Wetlands International [24] 2004.

\subsection{Various Data}

\subsubsection{Hotspot (Fire) Data}

Eighteen years of hotspot (HS, temperature anomaly) data detected by moderate resolution imaging spectroradiometer (MODIS) on the Terra and Aqua satellites are used to evaluate fires in boreal forests. MODIS HS data collected from 2002 to 2019 were obtained from NASA FIRMS (Fire Information for Resource Management System, https://firms2.modaps.eosdis.nasa.gov/download/ (Accessed 6 June 2020)). We use only the spatial and temporal (latitude, longitude and acquisition date and time) hotspot data in this study. The number of daily hotspots is used to identify fire activities and the fire year.

\subsubsection{OLR-MC Index}

The OLR-MC (rain-related index derived from outgoing longwave radiation (OLR), MC: maritime continent) data were obtained from the Japan Meteorological Agency (https://www.data.jma.go.jp/ gmd/cpd/db/diag/2018/index/html/soiolru/index_html_soiolru_2018.html (Accessed 6 June 2020)). The OLR-MC index monitors convective activity in Indonesia (5 N-5 S, 110-135 E) and used to identify a relationship with fire occurrence in Kalimantan. One study showed a high negative correlation between OLR and rainfall in South East Asia [9].

\subsubsection{Rainfall Data}

Some rainfall data are used in this report to compensate missing data, mainly in 2019. daily rainfall data were needed to estimate the daily change in groundwater level (GWL).

(1) Weather station rainfall data

Rainfall data measured at the Tjilik Riwut Meteorology Station (TRMS) [25], Palangkaraya (2.22 S, 113.95 E, 'A' in Figure 1) were used.

Generally speaking, Indonesian meteorological records lack data. In particular, there was much missing data on rainfall in 2019. But several Japanese researchers, including us, continue to collect rainfall data in collaboration with Indonesian researchers, enabling about 40 years (from 1978 to 2018) 
rainfall data to be recorded. Long-term data are useful for calculating average rainfall during dry and wet seasons, for example.

(2) Satellite rainfall data

Daily rainfall data provided by Japan Aerospace Exploration Agency (JAXA) [26] were used to estimate groundwater level during the fire (dry) season. We downloaded rainfall data by setting a target rectangle region in Palangkaraya (see a black dotted line rectangle in Figure 1).

(3) Estimated rainfall using OLR

Using the above-mentioned OLR-MC index, we analyzed the relationship between OLR values and rainfall data. The OLR value at point $\mathrm{O}(2.21 \mathrm{~S}, 114 \mathrm{E}$, ' $\mathrm{O}$ ' in Figure 1) was read from the OLR contour map.

Daily values and daily long-term mean values were estimated from (3-1) NOAA daily (non-interpolated) OLR [27] and (3-2) NOAA Interpolated OLR [28,29], respectively. daily values and daily long-term mean values were estimated from a correlation equation between OLR values and weather rainfall data at TRMS.

\subsubsection{Ground Water Level (GWL) Data}

Ten-year (1997-2006) GWL measurements [30] were averaged to develop a GWL simulation model. GWL was measured near point $\mathrm{U}(2.32 \mathrm{~S}, 113.9 \mathrm{E}$, ' $\mathrm{U}$ ' in Figure 1) on the upper catchment of the Sebangau River about $800 \mathrm{~m}$ from the forest edge and $2 \mathrm{~km}$ from the river along the logging railway on the right bank of the Sebangau River. The depth of peat near the measurement point is approximately $3 \mathrm{~m}$ [30]. Unfortunately, the measuring equipment was stolen in 2014, so the data location in 2015 and 2019 is near ' $U$ ' (ca. $0.9 \mathrm{~km}$ northeast of ' $U$ ').

\subsubsection{ENSO Data}

One of ENSO (El Niño-Southern Oscillation) indices, Niño 3.4, is obtained from the National Weather Service, Climate Prediction Center, NOAA [31].

\section{Ground Water Level (GWL) Simulation (MODEL 0)}

We used one-dimensional GWL model [32,33].

The water balance equation is expressed as [32]:

$$
\Delta S=R-(Q+E)
$$

where $\Delta \mathrm{S}$ is the change in storage of groundwater, $\mathrm{R}$ is rainfall, $\mathrm{Q}$ is the sum of surface runoff, transpiration, interflow and surface detention, E is evapotranspiration. The daily change of GWL was calculated by the following formula:

$$
\Delta S=((G W L \text { of the day })-(G W L \text { of the previous day })) / \Delta t=R-(Q+E)
$$

where $\Delta \mathrm{t}=$ one day, $\mathrm{Q}=0, \mathrm{E}$ is assumed as $8 \mathrm{~mm} \mathrm{day}^{-1}$ then,

$(\mathrm{GWL}$ of the day $)=(\mathrm{GWL}$ of the previous day $)+\mathrm{R}-8$

where $\mathrm{E}$ (evapotranspiration) is assumed as $8 \mathrm{~mm}^{-1}$ day $^{-1}$ by considering rate of GWL decrease derived from GWL data (1997-2006) [30]. We ignore the value of $Q$ because all component of $Q$ are soil surface processes $(\mathrm{Q}=0)[32]$. 


\section{Results}

\subsection{Annual Hotspot (Fire) Trend in Kalimantan}

The total annual number of hotspots (HSs) in each of the 18 years (2002-2019) is summarized in Table 2, which is arranged in descending order of the annual number of HSs in the MRP+ region (vertical row named as '(1) HS MRP+'). The annual number of HSs detected in Kalimantan Island (including Malaysia and Brunei) is also added in vertical row named as '(2) HS Kalimantan' in Table 2. The difference in the number of HSs-(2) HS Kalimantan in Table 2-between 2014 (top 7th) and 2012 (top 8th)-is large or ca. 13,000. The top seven years from Rank 1 (2015) to Rank 7 (2014) are called 'fire year' in this report.

Table 2. Annual number of hotspots in the study are (MRP+) and whole Kalimantan.

\begin{tabular}{|c|c|c|c|c|c|c|c|c|c|}
\hline Rank & Year & $\begin{array}{l}\text { (1) HS } \\
\text { MRP+ }\end{array}$ & $\begin{array}{c}\text { (2) HS } \\
\text { Kalimantan }\end{array}$ & $(1) /(2) \%$ & Rank & Year & $\begin{array}{l}\text { (1) HS } \\
\text { MRP+ }\end{array}$ & $\begin{array}{c}\text { (2) HS } \\
\text { Kalimantan }\end{array}$ & $(1) /(2) \%$ \\
\hline 1 & 2015 & 19,936 & 78,708 & 25.3 & 10 & 2018 & 3452 & 16,892 & 20.4 \\
\hline 2 & 2006 & 11,754 & 55,852 & 21.0 & 11 & 2011 & 3351 & 17,097 & 19.6 \\
\hline 3 & $2019^{1}$ & 11,070 & 42,714 & 25.9 & 12 & 2003 & 2367 & 18,612 & 12.7 \\
\hline 4 & 2002 & 10,745 & 46,487 & 23.1 & 13 & 2013 & 1451 & 12,225 & 11.9 \\
\hline 5 & 2009 & 10,044 & 40,830 & 24.6 & 14 & 2007 & 810 & 11,263 & 7.2 \\
\hline 6 & 2004 & 7220 & 36,333 & 19.9 & 15 & 2017 & 311 & 5371 & 5.8 \\
\hline 7 & 2014 & 6677 & 32,384 & 20.6 & 16 & 2016 & 214 & 11,003 & 1.9 \\
\hline 8 & 2012 & 4025 & 19,212 & 21.0 & 17 & 2008 & 164 & 8150 & 2.0 \\
\hline 9 & 2005 & 3747 & 16,249 & 23.1 & 18 & 2010 & 85 & 6128 & 1.4 \\
\hline & & & & & \multicolumn{2}{|c|}{ Total } & 97,423 & 475,510 & 20.5 \\
\hline
\end{tabular}

${ }^{1}$ Fires in 2019 occurred El Niño index is neutral.

The study area MRP + is 32,400 $\mathrm{km}^{2}$ in size, which accounts for about $6 \%$ of Kalimantan Island $\left(544,150 \mathrm{~km}^{2}\right)$. Nevertheless, about 20\% (see the ratio (1)/(2) in Table 2) of all Kalimantan fires have occurred in the study area. This suggests that peatland fires existing in MRP+ contribute greatly. The total number of top seven fires in MRP+ was 77,446 , about $80 \%$ of the total number $(97,423)$ for 18 years. Most fires in MRP+ occurred in the top seven fires.

\subsection{Effective Fire Index (Comparison of OLR-MC and Niño 3.4)}

\subsubsection{OLR-MC Index}

OLR-MC index is introduced as an index for predicting peatland fire occurrence in the study area, MRP+. Figure 2 shows monthly HSs and OLR-MC index trends from 2002 to 2019. The number of monthly HSs exceeding 300 is indicated by ' $X^{\prime}$ marks and line graphs. Monthly OLR-MC index readings of less than 0.2 are shown by solid circles and dotted line graphs. For the smoothed line graph of OLR-MC, the 5-month running mean values of the OLR-MC index are obtained and drawn by solid circles and thick line graphs in Figure 2.

Figure 2 shows that each HS peak month of the top four fire years-2015, 2006, 2019 and 2002-occurred under low OLR-MC index readings of between -1 and -2 . In the other (5th to 7th) fire years, the HS peak month occurred under OLR-MC index readings of between -0.5 and -1 . The largest number of HSs (=8891) in September 2015 (top fire year) occurred with the lowest OLR-MC index reading $(=-1.9)$. To clarify the relationship between the number of HSs and OLR-MC index readings, a regression equation is obtained:

$$
\text { HSs }=1537.2-2000.6 \text { OLR }+566.7 \mathrm{OLR}^{2}\left(\mathrm{R}^{2}=0.8389\right)
$$

where HSs is the number of HSs, OLR is the OLR-MC index.

The relatively high value of decision coefficient $\left(R^{2}=0.84\right)$ suggests that there was a good correlation between the number of HSs and the OLR-MC index over the last 18 years, including 2019. 
The number of observed HSs and estimated HSs using Equation (4) (OLR-MC index $=-1.9)$ in 2019 was 7334 and 7384, respectively.

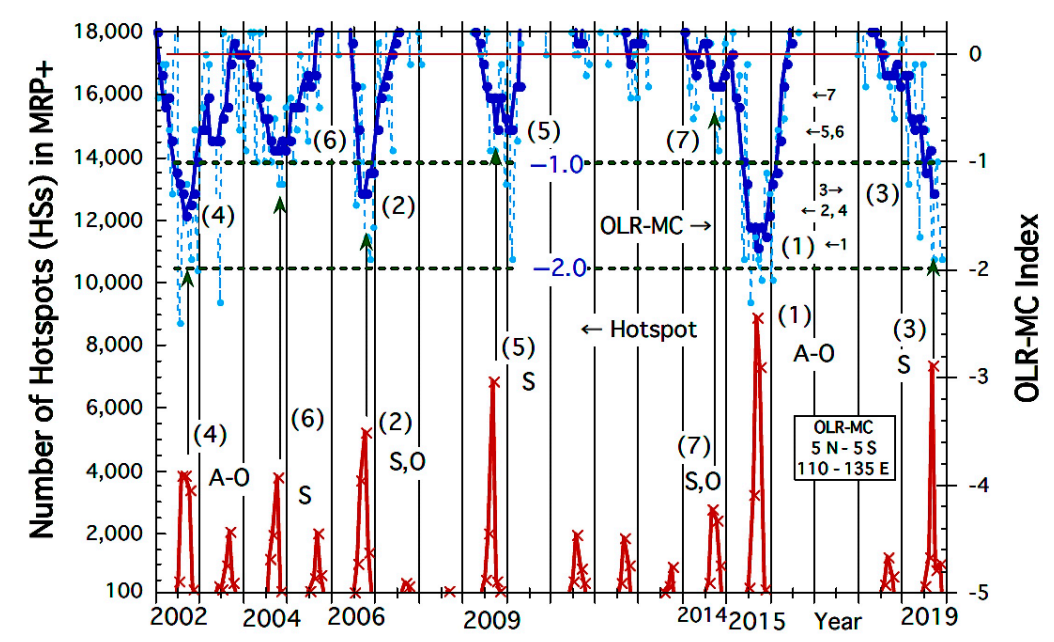

Figure 2. Monthly number of hotspots (HSs) and OLR-MC. (1)-(7) rank the top seven fire years. The fire peak month is shown in abbreviated form A,S and O stand for August, September and October, respectively. A-O means three active fire months from August to October.

\subsubsection{Niño 3.4 Index}

The most referenced fire index in Indonesia is Niño 3.4 index, one of the ENSO indices. Niño 3.4 is introduced here to identify the relationship with the number of HSs in study area MRP+. Figure 3 shows monthly HSs and Niño 3.4 index trends from 2002 to 2019. The number of monthly HSs exceeding 300 is indicated by ' $X$ ' marks and line graphs. Monthly Niño 3.4 index readings larger than -0.2 are shown by solid circles and dotted line graphs. For the smoothed line graph of Niño 3.4, the 5-month running mean values of Niño 3.4 index are obtained and drawn by solid circles and thick line graphs in Figure 3.

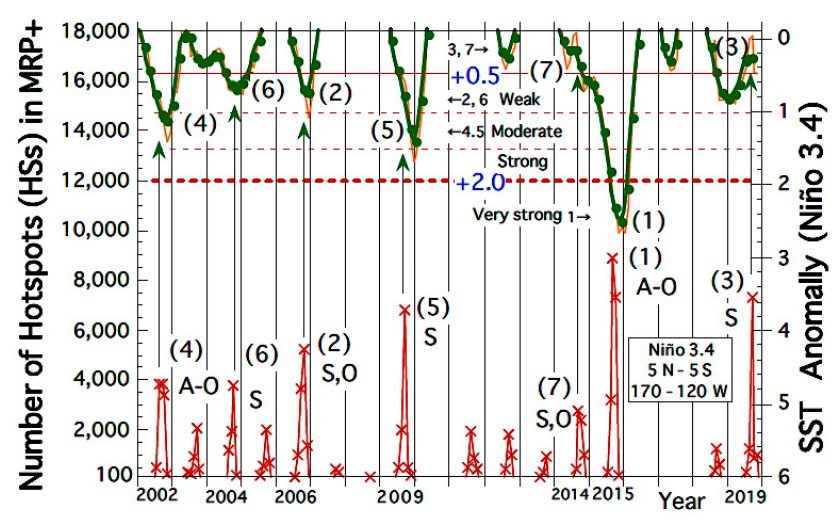

Figure 3. Monthly number of hotspots (HSs) and Niño 3.4. See captions in Figure 2. SST: sea-surface temperature.

Figure 3 shows that each HS peak month of most fire years, excluding 2019, occurred under high positive Niño 3.4 index readings (note the inversed scale of $Y$ axis on the right side of Figure 3). The largest number of HSs (=8891) in September 2015 (top fire year) occurred under the highest Niño 3.4 index reading (=2.1). Other top fire years, excluding 2019, occurred under a positive Niño 3.4 index reading from 0.5 to 1.5. To clarify the relationship between the number of HSs and Niño 3.4 index readings, a regression equation is obtained:

$$
\text { HSs }=2334.1+2322.1 \mathrm{Niño}+429.6 \mathrm{Niño}^{2}\left(R^{2}=0.6030\right)
$$


where HSs is the number of HSs, and Niño is the Niño 3.4 index.

The number of observed HSs and estimated HSs using Equation (5) (Niño 3.4 index $=-0.04$ ) in 2019 were 7334 and 2242, respectively. This large underestimated HS value and the relatively low value of decision coefficient $\left(R^{2}=0.60\right)$-compared with that of $\left(R^{2}=0.84\right)$ for OLR-MC index—suggests that the Niño 3.4 index will work for fire occurrence related to ENSO, but will not be suitable for fires like those in 2019 supposed to be under climate-change conditions.

The OLR-MC index shows a stronger correlation with active peatland fires than the conventional ENSO index, and is likely to be able to respond to future fire forecasts under climate-change conditions.

\subsubsection{Comparison of OLR-MC and Niño 3.4}

The relationship between the number of HSs and OLR-MC index is shown in Figure 4a. Figure 4a shows a good fitting of the regression equation (Equation (4)). The difference (ENSO neutral year) in 2019 is 50 HSs (=7384-7334). The largest difference is ca. -3000 HSs in 2009.

On the other hand, Figure $4 \mathrm{~b}$ shows relatively large differences in each HSs compared with the results of OLR-MC index shown in Figure 4a. The largest difference is -5092 HSs (=2242-7334) in 2019 (Niño 3.4 index = 0.6). The second largest difference is ca. -3000 HSs in 2009.

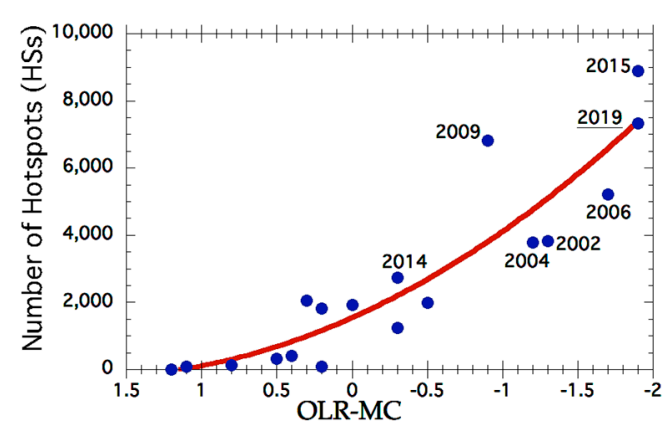

(a) OLR-MC index $\left(\mathrm{R}^{2}=0.84\right)$

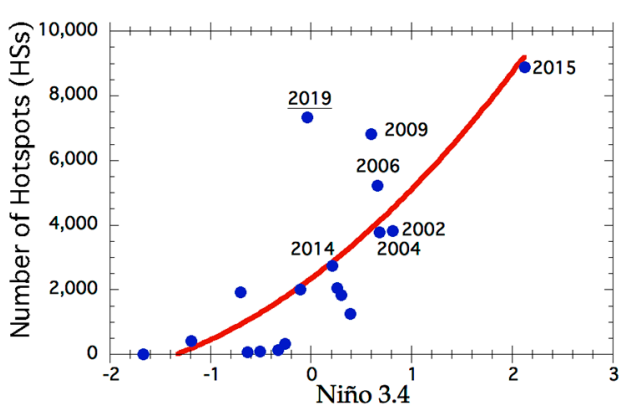

(b) Niño 3.4 index $\left(\mathrm{R}^{2}=0.60\right)$

Figure 4. Comparison of OLR-MC and Niño 3.4.

\subsection{Comparison of Rainfall Data}

\subsubsection{Estimated Rainfall using OLR}

The OLR-MC index already showed a good correlation with HS in Section 4.2.1. A report [34] showed there are negative correlations between OLR and rainfall over equatorial regions (0-10 S). Therefore, we compared the daily average rainfall data from 1978 to 2018 measured at TRMS ('A' in Figure 1) and the long-term mean OLR values (1981-2010) at point $\mathrm{O}(2.21 \mathrm{~S}, 114 \mathrm{E}$, 'O' in Figure 1) obtained from the OLR contour map. OLR values were smoothed by the 5-day running mean values.

Figure 5 shows the relationship between averaged daily rainfall data (TRMS) and smoothed OLR. A total of 161 data ( $\mathrm{DN}=170-330$ ) were plotted in Figure 5 daily rainfall was estimated using the linear correlation equation:

$$
\text { daily rainfall }(\mathrm{mm})=43.881-0.16986 \text { OLR }\left(\mathrm{R}^{2}=0.52965\right)
$$




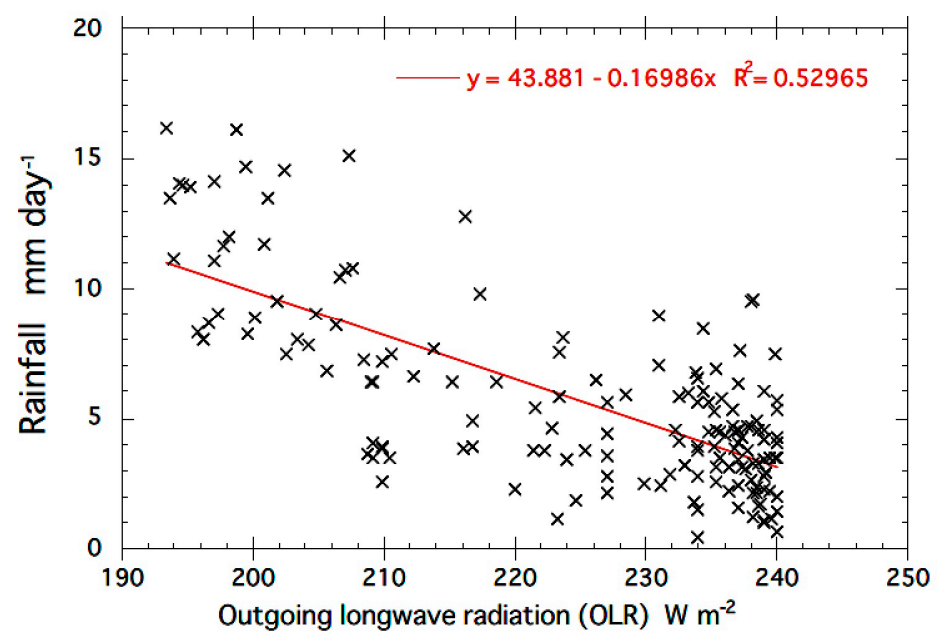

Figure 5. Averaged rainfall (TRMS) and OLR.

\subsubsection{Rainfall during Dry Season}

Rainfall trend during dry season in Palangkaraya are shown in Figure 6. The dry season usually begins in June and ends in October, with the rainy season from November to May. As daily rainfall tends to decrease gradually from June 19-Day Number $(\mathrm{DN})=170$ ) —we make two accumulated rainfall curves, one for the 41 years average rainfall from 1978 to 2018 and another for the top six fire years excluding 2019.

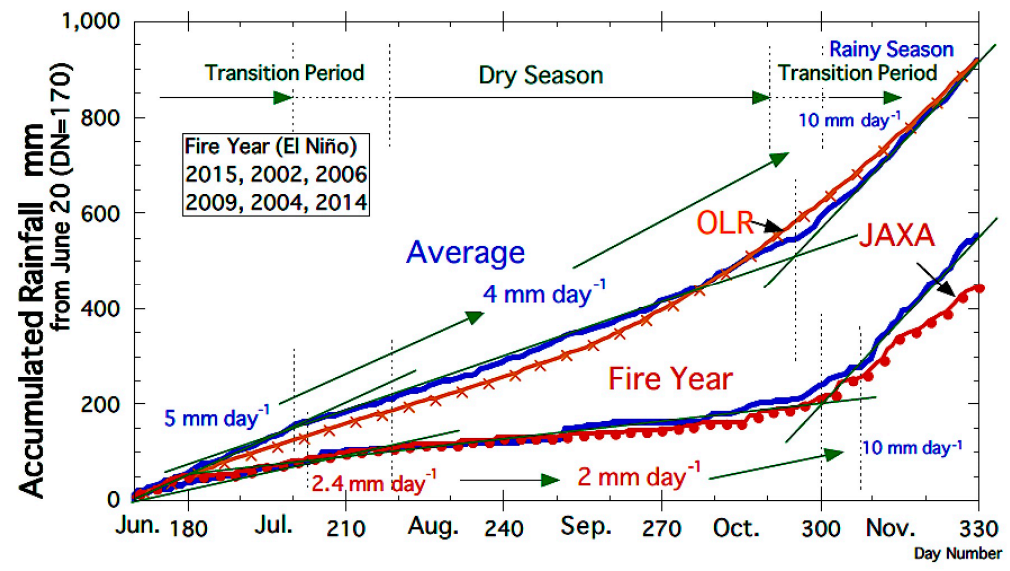

Figure 6. Averaged rainfall trend and fire year trend. Averaged and fire year rainfall data from TRMS. Estimated averaged rainfall data from OLR. Fire year rainfall data from JAXA.

Over those 41 years, the average daily rainfall was $4 \mathrm{~mm} \mathrm{day}^{-1}$ in the dry season, $10 \mathrm{~mm} \mathrm{day}^{-1}$ in the rainy season and $5 \mathrm{~mm} \mathrm{day}^{-1}$ in the transition period from $\mathrm{DN}=170$. The 30-year average rainfall estimated by OLR shows a similar trend with weather station data. As a result of this comparison, we may say the estimated rainfall using OLR can be applied to various analyses because the margin for error is not so large.

Two sets of average rainfall data of the top six fire years, excluding 2019, are also shown in Figure 6. The 41 years average daily rainfall for the top six fire years is $2 \mathrm{~mm} \mathrm{day}^{-1}$ in the dry season, $10 \mathrm{~mm} \mathrm{day}^{-1}$ in the rainy season and $2.4 \mathrm{~mm} \mathrm{day}^{-1}$ in the transition period. Rainfall for the top six fire years in the dry season is half that of 41-year average. Figure 6 clearly shows severe drought conditions. The JAXA-averaged rainfall for the top six fire years also shows a similar trend with weather station data. From this comparison, we may say the JAXA rainfall data will be applicable for various analyses because the margin for error is not so large. 


\subsection{Fire Occurrence Trends in Fire Years}

Figure 7 shows fire occurrence trends from June $20(\mathrm{DN}=170)$ of the fire years including 2019. A thick dotted line in Figure 7 shows averaged fire occurrence trends from 2002 to 2018. From the curve of the accumulated daily number of hotspots in Figure 7, the fire occurrence tendency of each fire year can be grasped. In Figure 7, straight lines are drawn on each accumulated hotspot (HS) curves of the fire year. These lines are useful to find fire activity, active fire periods (with start and end dates) and duration. Fire rate (HS day ${ }^{-1}$ ) derived from the gradient of the straight line is used to evaluate fire activities.

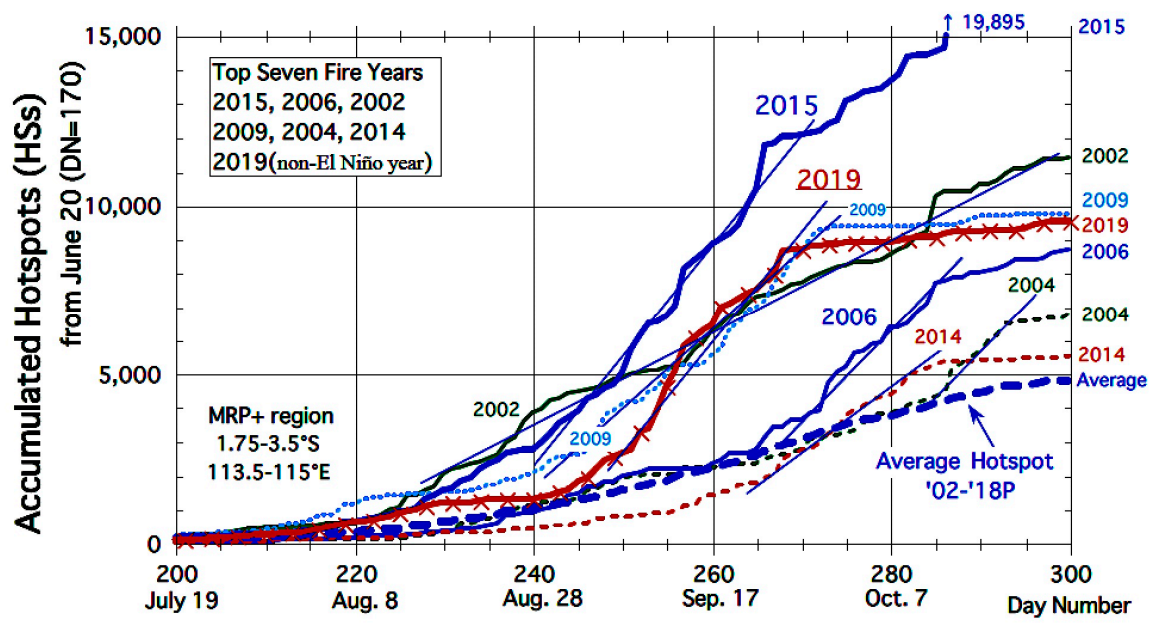

Figure 7. Trends for the seven fire years.

Intense fires in 2015 (the top fire year) and 2002 lasted ca. 60 days from late August to late October. Their fire rates were ca. $280 \mathrm{HS} \mathrm{day}^{-1}$ in 2015 and ca. $120 \mathrm{HS} \mathrm{day}^{-1}$ in 2002. Fires in 2009 and 2019 became active from early September and continued for ca. 25 days with an average of ca. 250 and 270 HS day $^{-1}$, respectively. Fires in 2006 and 2014 became active from late September and lasted until early October with ca. 270 and $190 \mathrm{HS}_{\text {per day }}{ }^{-1}$. Active fires in 2004 occurred in mid-October with 270 HS per day ${ }^{-1}$. The fire rates of fire years were 1.7 to 4 times higher than the 17-year (2002 to 2018) average of HS per day ${ }^{-1}$.

\subsection{Hotspot (Fire) Simulation (MODEL-0)}

\subsubsection{Simulation (MODEL-0) Results for Fire Years}

Figure 8 shows the average fire occurrence trend of the fire year from June $20(\mathrm{DN}=170)$ and estimated GWL using MODEL-0. Additional straight lines on an average accumulated HS curve are drawn to define several fire stages. These stages are inherently derived from fire occurrence trends on the average accumulated HS curve. Here, we could define a few fire stages by gradients of several straight lines and named them Stage 1, Stage 2 and Stage 3, which are shown in Figure 8. We follow the stage numbering (Stage 1, Stage 2 and Stage 3) in the previous report [21].

Fires in Stage 1 (fire rate ca. $10 \mathrm{HS}$ day $^{-1}$ ) start from the middle of July and end in late July. Then, fires in Stage 2 (fire rate ca. $70 \mathrm{HS}_{\text {day }}{ }^{-1}$ ) begin from the middle of August and last until late August. Finally, most active fires in Stage 3 (fire rate ca. $160 \mathrm{HS} \mathrm{day}^{-1}$ ) occur from the beginning of September and last until the end of October. However, the fire will continue until early November when the full rainy season begins.

Estimated GWL using MODEL-0 in Figure 8 was obtained by using average rainfall of top fire year (TRMS). Equation (3) ((GWL of the day) $=(\mathrm{GWL}$ of the previous day $)+\mathrm{R}-8)$ is used to estimate daily GWL. Calculation starts from June 19. Initial GWL on June 19 is set to $0 \mathrm{~mm}$ from averaged groundwater level [30]. GWL of next day (June 20) is $+3.3 \mathrm{~mm}(=0+\mathrm{R}-8$ (where $\mathrm{R}$ (rainfall on June 20) 
is $11.3 \mathrm{~mm}$ from average TRMS rainfall data). Like this manner, daily GWL is estimated. GWL becomes under $-500 \mathrm{~mm}$ on September $1(\mathrm{DN}=244)$.

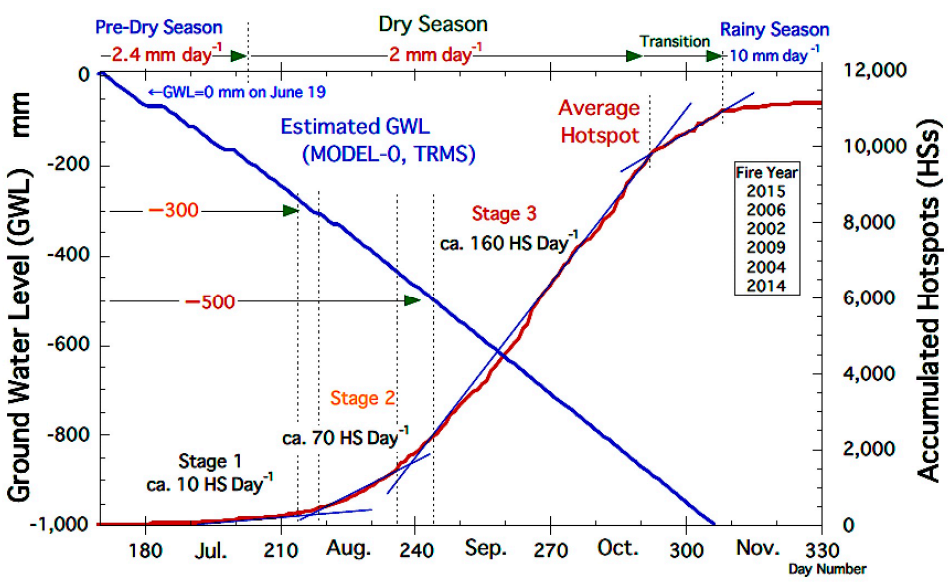

Figure 8. Average fire activity of El Niño fire year and estimated GWL using MODEL-0. Rainfall data from TRMS. GWL on June $19(\mathrm{DN}=170)$ were set to $0 \mathrm{~mm}$.

The fire activity of the three fire stages was dependent on the GWL depth, with thresholds of ca. $-300 \mathrm{~mm}$ and ca. $-500 \mathrm{~mm}$. The three fire stages are classified into a surface fire, a shallow peat fire and a deep peatland fire [21]. This is because the lower the GWL, the lower the moisture content of the peat and the more easily the peat can be burned [35,36]. The onset of peatland fire is confirmed by measuring air pollutant gases and particulate matter from peat burning. In fact, increasing trends in carbon monoxide $(\mathrm{CO})$, sulfur dioxide $\left(\mathrm{SO}_{2}\right)$, and particulate matter (PM10) were observed from mid-August 2002 [19]. Increased $\mathrm{SO}_{2}$ from around $5 \times 10^{-6} \mathrm{~g} \mathrm{~m}^{-3}$ in early August to $85.8 \times 10^{-6} \mathrm{~g} \mathrm{~m}^{-3}$ in mid-October was thought to be primarily due to peat fires, as there are no other major sources of $\mathrm{SO}_{2}$ (such as industry) nearby. $\mathrm{CO}$ and PM10 also began to increase in early August. These increases are due to the low-temperature, underground peatland fire (smoldering combustion under low levels of oxygen). The increase in $\mathrm{CO}, \mathrm{SO}_{2}$ and $\mathrm{PM} 10$ at the same time can be considered one of the characteristics of peatland fires.

\subsubsection{Simulation (MODEL-0) Results for 2015 (top) \& 2006 (2nd)}

Figure 9 shows the relationship between fire trends and GWL in 2015 (the top fire year, HSs = 19,936, Niño $3.4=2.12$ (very strong), OLR-MC = -1.9). In Figure 9, GWL measured values are plotted in order to evaluate the validity of MODEL-0 (GWL estimation model). From Figure 9, we could see the following: Fires in 2015 became active (ca. $160 \mathrm{HS}_{\text {day }}{ }^{-1}$ ) from mid-August when the GWL was below $-300 \mathrm{~mm}$. In early September, after the GWL fell below $-500 \mathrm{~mm}$, the fire became very intense (ca. $370 \mathrm{HS} \mathrm{day}^{-1}$ ) and continued until late October. The fires in 2015 were weakening due to the rainy and hazy conditions in September, but the fires continued because of the low GWL (under $-500 \mathrm{~mm}$ ).

Figure 10 shows the relationship between fire trends and GWL in 2006 (the top second fire year, HSs $=11,754$, Niño $3.4=0.66$ (weak), OLR-MC = -1.7). In Figure 10, GWL measured values are plotted in order to evaluate the validity of MODEL-0.

From Figure 10, we could see the following: Fires in 2006 became active (ca. $70 \mathrm{HS}^{\text {day }}{ }^{-1}$ ) from mid-August when the GWL was below $-300 \mathrm{~mm}$. In mid-September, after the GWL fell below $-500 \mathrm{~mm}$, the fire became very intense (ca. $240 \mathrm{HS} \mathrm{day}^{-1}$ ) and continued until mid-November. The fires in 2006 were weakening due to the rainfalls of $19 \mathrm{~mm}$ and $9.6 \mathrm{~mm}$ in September and October, but the fires continued because of the low GWL (under $-500 \mathrm{~mm}$ ). 


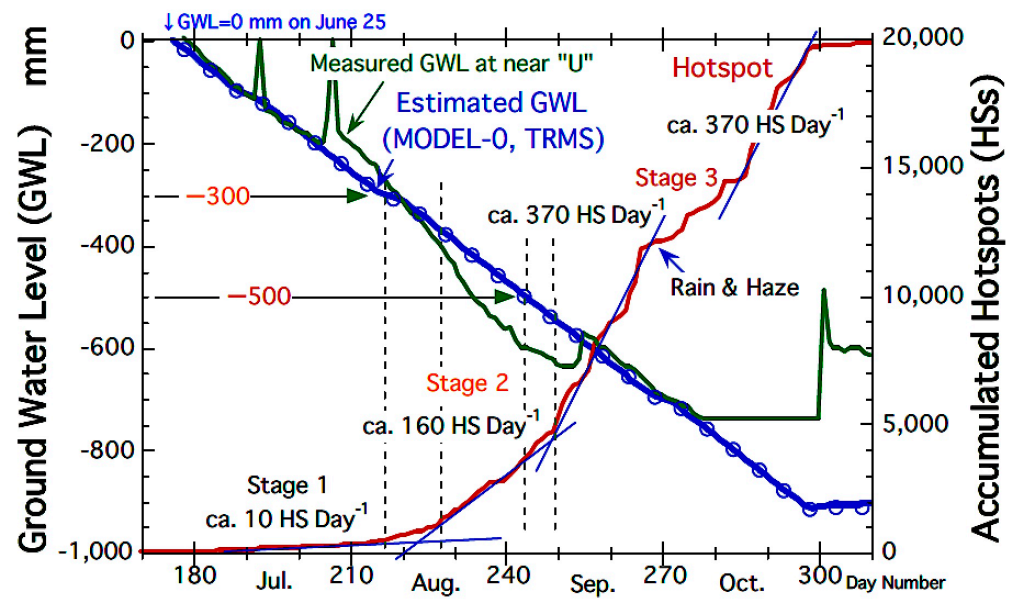

Figure 9. Fire trend and estimated GWL in 2015. Rainfall data from TRMS, GWL on June $25(\mathrm{DN}=176)$ were set to $0 \mathrm{~mm}$.

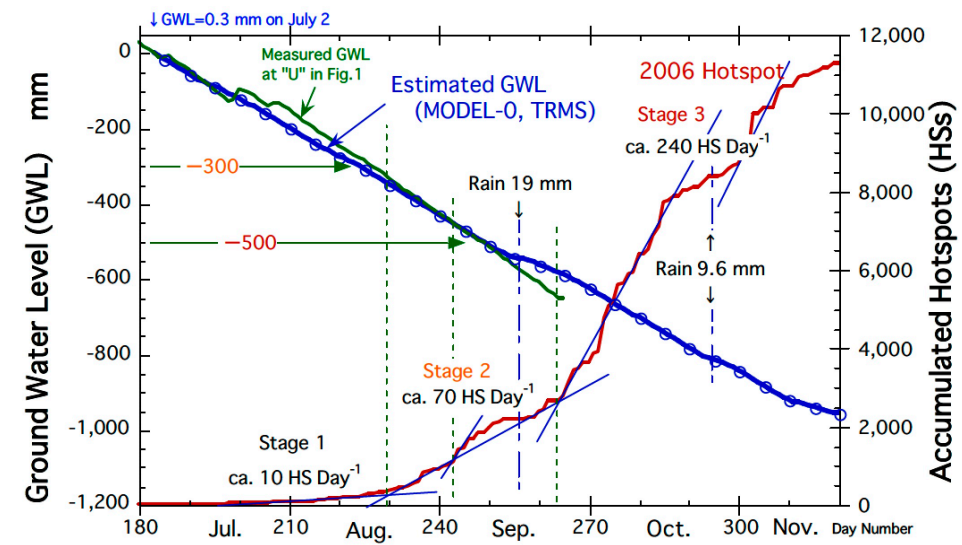

Figure 10. Fire trend and estimated GWL in 2006. Rainfall data from TRMS, GWL on July $2(\mathrm{DN}=183$ ) were set to $0 \mathrm{~mm}$. GWL data measured at 'U' $(2.32 \mathrm{~S}, 113.9 \mathrm{E})$ in Figure 1.

\subsubsection{Simulation (MODEL-0) Results for 2019 (3rd)}

Figure 11 shows the relationship between fire trends and GWL in 2019 (the third top fire year, non-El Niño year, HSs = 11,070, Niño $3.4=-0.04$ (neutral), OLR-MC = -1.9). In Figure 11, GWL measured values are plotted in order to evaluate the validity of MODEL-0. Here, we adjusted the GWL measured for comparison with estimated GWL. The GWL measured was high until late July, probably because of the river's high water level.

From Figure 11, we can see the following: Fires in 2019 became active (ca. $40 \mathrm{HS} \mathrm{day}^{-1}$ ) from late July when the GWL was below $-300 \mathrm{~mm}$. In late August, after the GWL fell below $-500 \mathrm{~mm}$, the fire became very intense (ca. $270 \mathrm{HS}^{\mathrm{day}}{ }^{-1}$ ) and continued until mid-November. The large difference between GWL measured values and the estimated GWL is mainly due to a different measuring position. However, the tendency of the GWL decrease is almost the same. The peatland fires in 2019 weakened due to the heavy rainfall of $44 \mathrm{~mm}$ in August, but they continued because the rain could not sufficiently moisten the peat (GWL was around $-450 \mathrm{~mm}$ ). A few days after the heavy rain, GWL began to decline again, and fires were very active when GWL fell to ca. $-500 \mathrm{~mm}$. The 2019 case demonstrates how effective MODEL-0 was in forecasting GWL. In particular, it is very important to predict the occurrence of deep peatland fires (fire stage 3), and MODEL-0 could do this for the 2019 case, if applied. 


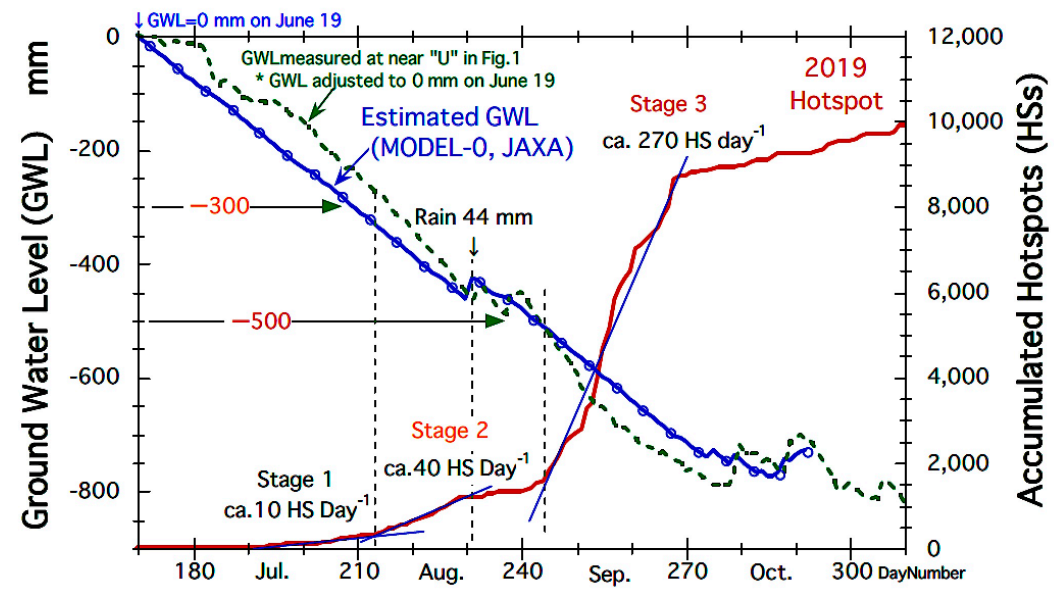

Figure 11. Fire trend and estimated GWL in 2019. Rainfall data from JAXA, GWL for MODEL-0 on June $19(\mathrm{DN}=170)$ were set to $0 \mathrm{~mm}$. GWL measured is adjusted to $0 \mathrm{~mm}$ on June 19 . GWL data measured at near ' $U$ ' in Figure 1.

\section{Discussion}

Many researchers have revealed peat-burning characteristics as well as the relationship with groundwater levels, carbon dioxide emissions, air pollution and ENSO. However, little research was carried out on: (1) predictive indicators other than ENSO for active peatland fires, and (2) the groundwater level (GWL) prediction model (MODEL-0) to evaluate the onset of active peatland fire, as described in this report.

\subsection{Predictive Indicators Other than ENSO Indices for Active Peatland Fires}

Until 2019, most peatland fires were associated with an El Niño event. Especially active peatland fires in 1982-83, 1997-98 and 2015 occurred under very strong El Niño conditions [1] However, active peatland fires broke out in 2019, unrelated to the El Niño phenomenon (see Figures 2 and 3) and could be linked to climate change. Preliminarily, we introduced the OLR-MC index (see 2.2.2) and examined the relationship with the number of HSs and OLR-MC index readings. As a result, the regression equation between fires (the number of HSs) and OLR-MC index readings showed a relatively high decision coefficient $\left(R^{2}=0.84\right)$. This suggested that there was a good correlation between the number of HSs and the OLR-MC index over the past 18 years, including 2019 (see Figure 2, Equation (4)).

On the other hand, a regression equation between fires (the number of HSs) and Niño 3.4 (one of the ENSO indices) had a relatively low decision coefficient $\left(R^{2}=0.60\right)$. In addition, there was a large difference between the number of observed HSs and estimated HSs from the regression equation regarding Niño 3.4 (index $=-0.04$ in 2019). The values were 7334 and 2242, respectively (see Figure 3, Equation (5)).

From the above results, we may conclude that an OLR index, such as OLR-MC, will be useful for analyzing future active fires related to both El Niño and climate change. In addition, this report compared various rainfall data. Results showed that the remote sensing and satellite data provided by JAXA and the estimated data using OLR are effective for rainfall analysis, such as that presented in this report.

\subsection{Groundwater Level (GWL) Prediction Model ((MODEL-0))}

Peatland fire could be classified into three stages, namely surface fire, surface peatland fire and deep peatland fire [21]. In this report, the authors proposed a one-dimensional groundwater level (GWL) prediction model (MODEL-0) to clarify the relationship between peatland fire activity and GWL. MODEL-0 calculates daily changes in GWL using daily precipitation (for simplicity, dry season evapotranspiration is assumed as constant). GWL is important for knowing the dry state of peat. 
From the average number of fire hotspots in the top six fire years (excluding 2019) and the daily change in GWL trend calculated from the average daily rainfall, peatland fires are divided into three stages as GWL penetrates deeper. The fire activity of the three stages was dependent on the GWL depth, with their threshold values being ca. $-300 \mathrm{~mm}$ and ca. $-500 \mathrm{~mm}$. Thus, MODEL-0 clarified the relationship between the fire activity of the three fire stages and GWL (see Figure 8).

Peatland fire analysis using MODEL-0 was successfully applied to the top three peatland fires in 2005, 2006 and 2019 (see Figures 9-11). MODEL-0 was able to estimate the groundwater level relatively well and could explain the active peatland fire occurrence depending on the groundwater level. In particular, MODEL-0 was also effective in the 2019 fire analysis, which was a neutral El Niño year, so it can be said that the possibility of responding to extreme weather supposed to be under climate change conditions was demonstrated.

\section{Conclusions}

We analyzed recent active peatland fires in the MRP+ region in Central Kalimantan from 2002 to 2019. The results allowed us to make the following conclusions:

(1) OLR-MC (monitoring convective activity in Indonesia using a rain-related index derived from the OLR) index is introduced as one of the fire indices for predicting peatland fire occurrence. The OLR-MC index showed a stronger correlation with active peatland fires than the conventional ENSO index and is likely to be able to respond to future fire forecasts supposed to be under climate change conditions (Figures 2 and 3).

(2) From the average fire trends in the top six fire years (El Niño years), excluding 2019, it was revealed that active fires occurred in three stages (Figure 8).

(3) The one-dimensional GWL prediction model (MODEL-0) is introduced to define three fire stages of the active peatland fire years (Figure 8).

(4) Peatland fire activities during three fire stages were dependent on the GWL-predicted values. Their GWL boundary values were ca. $-300 \mathrm{~mm}$ and ca. $-500 \mathrm{~mm}$. Three fire stages are called surface fire, shallow peatland fire and deep peatland fire (Figure 8).

(5) The 2015 and 2006 fires occurred in three fire stages defined by the estimated GWL using MODEL-0 and became very intense from September. Their fire rates were ca. 370 and ca. $240 \mathrm{HS}_{\mathrm{day}^{-1}}{ }^{-1}$ respectively (Figures 9 and 10).

(6) The 2019 fires under neutral El Niño conditions also occurred in three fire stages defined by the estimated GWL using MODEL-0 and became very intense (ca. $270 \mathrm{HS} \mathrm{day}^{-1}$ ) in September (Figure 11). The 2019 case demonstrated how effective MODEL-0 was in forecasting GWL. In other words, the peatland fire situation (fire stages 1-3) can be ascertained by the GWL value derived from MODEL-0. In particular, it is important to predict the occurrence of deep peatland fires (fire stage 3) and MODEL-0 could predict it.

(7) A method for estimating rainfall using the OLR distribution map was developed. Rainfall at any arbitrary location can be estimated with this method. MODEL- 0 can be applied in any target region to determine the fire stages from the estimated GWL (Figures 5 and 6).

Author Contributions: Most part of research articles done by H.H.; supervision, A.U.; project administration and funding acquisition, D.N. All authors have read and agreed to the published version of the manuscript.

Funding: This research is partially funded by Ministry of Agriculture, Forestry and Fisheries of Japan grant to CIFOR.: Project named "Enhancing climate-resilient livelihoods in boreal and tropical high carbon forests and peatlands".

Acknowledgments: We are grateful for uninterpolated and interpolated OLR data provided by NOAA/OAR/ESRL PSD (Boulder, Colorado, USA) and Niño 3.4 data provided by the National Weather Service, Climate Prediction Center, NOAA, USA.

Conflicts of Interest: The authors declare no conflict of interest. 


\section{References}

1. Page, S.; Rieley, J.; Hoscilo, A.; Spessa, A.; Weber, U. Current fire regimes, impacts and the likely changes-IV: Tropical Southeast Asia. In Vegetation Fires and Global Change-Challenges for Concerted International Action. A White Paper Directed to the United Nations and International Organizations; Goldberg, J.G., Ed.; Kessel Publishing House, KesselsKramer: Amsterdam, The Netherlands, 2013; pp. 91-96.

2. Weisse, M.; Goldman, L. 2017 Was the Second-Worst Year on Record for Tropical Tree Cover Loss. Global Forest Watch Blog. Available online: https://blog.globalforestwatch.org/data-and-research/2017-was-thesecond-worst-year-on-record-for-tropical-tree-cover-loss (accessed on 6 May 2020).

3. Langner, A.; Siegert, F. Spatiotemporal fire occurrence in Borneo over a period of 10 years. Glob. Chang. Biol. 2009, 15, 48-62. [CrossRef]

4. Schindele, W.; Thoma, W.; Panzer, K. The forest fire 1982/3 in East Kalimantan, Part 1: The fire, the effects, the damage and technical solutions. In FR-Report No. 5: Investigation of the Steps Needed to Rehabilitate the Areas of East Kalimantan Seriously Affected by Fire; Jakarta, German Forest Inventory Service Ltd. for German Agency for Technical Cooperation (GTZ) and International Tropical Timber Organization (ITTO): Yokohama, Japan, 1989.

5. Lennertz, R.; Panzer, K. Preliminary assessment of the drought and forest fire damage in Kalimantan Timur. In East Kalimantan; Jakarta, DFS German Forest Inventory Service Ltd. for Deutsche Gesellschaft fur Technische Zusammenarbeit (GTZ): Bonn and Eschborn, Germany, 1984.

6. Tacconi, L. Fires in Indonesia: Causes, Costs and Policy Implications; CIFOR Occasional Paper No. 38; CIFOR: Bogor, Indonesia, 2003.

7. Reuters. Greenpeace Blasts Indonesia for not Imposing Tough Penalties for Forest Fires. 2019. Available online: https:/www.nst.com.my/world/2019/09/524250/greenpeace-blasts-indonesia-not-imposing-toughpenalties-forest-fires (accessed on 18 January 2020).

8. Jakarta Post. Fires in Indonesia Burn 1.6m ha of Land, Mostly Former Forests: Satellite Data. Available online: https://www.thejakartapost.com/life/2019/12/02/fires-in-indonesia-burn-1-6m-ha-of-land-mostlyformer-forests-satellite-data.html (accessed on 18 January 2020).

9. Liebmann, B.; Marengo, J.A.; Glick, J.D.; Kousky, V.E.; Wainer, I.C.; Massambani, O. A Comparison of Rainfall, Outgoing Longwave Radiation, and Divergence over the Amazon Basin. J. Clim. 1998, 11, $2898-2909$. [CrossRef]

10. Lim, E.S.; Wong, C.J.; Abdullah, K.; Poon, W.K. Relationship between outgoing longwave radiation and rainfall in South East Asia by using NOAA and TRMM satellite. In Proceedings of the 2011 IEEE Colloquium on Humanities, Science and Engineering, Penang, Malaysia, 5-6 December 2011.

11. Hoscilo, A.; Page, S.E.; Tansey, K.J. Repeated and extensive fire as the main driver of land cover change in Block C of the former Mega Rice Project. In Proceedings of the 13th International Peat Congress: After Wise Use—the Future of Peatlands; Farrell, C., Feehan, J., Eds.; International Peat Society: Tullamore, Ireland, 2008; pp. 206-208.

12. Hoscilo, A.; Page, S.E.; Wosten, H.; Jauhiainen, J.; Silvius, M.; Rieley, J.; Ritzema, H.; Tansey, K.; Graham, L.; Vasander, H. Restoration ecology of lowland tropical peatlands in Southeast Asia: Current knowledge and future research directions. Ecosystems 2008, 12, 888-905.

13. Page, S.E.; Hoscilo, A.; Langner, A.; Tansey, K.J.; Siegert, F.; Limin, S.; Rieley, J.O. Tropical peatland fires in Southeast Asia. In Tropical Fire Ecology: Climate Change, Land Use and Ecosystem Dynamics; Cochrane, M.A., Ed.; Springer: Berlin/Heidelberg, Germany, 2009.

14. Vetrita, Y.; Cochrane, M.A. Fire frequency and related land-use and land-cover changes in Indonesia's peatlands. Remote Sens. 2019, 12, 5. [CrossRef]

15. Schultz, M.G.; Heil, A.; Hoelzemann, J.J.; Spessa, A.; Thonicke, K.; Goldammer, J.G.; Held, A.C.; Pereira, J.M.C.; van het Bolscher, M. Global wildland fire emissions from 1960 to 2000. Glob. Biogeochem. Cycles 2008, 22, 1-17. [CrossRef]

16. Van der Werf, G.R.; Randerson, J.T.; Giglio, L.; Collatz, G.J.; Kasibhatla, P.S. Interannual variability in global biomass burning emission from 1997 to 2004. Atmos. Chem. Phys. 2006, 6, 3423-3441. [CrossRef]

17. Setyawati, W.; Suwarsono. Carbon emission from peat fire in 2015. IOP Conf. Ser. Earth Environ. Sci. 2018, 166, 1-7. [CrossRef] 
18. Kiely, L.; Spracklen, D.V.; Wiedinmyer, C.; Conibear, L.; Reddington, C.L.; Archer-Nicholls, S.; Lowe, D.; Arnold, S.R.; Knote, C.; Khan, M.F. New estimate of particulate emissions from Indonesian peat fires in 2015. Atmos. Chem. Phys. 2019, 19, 11105-11121. [CrossRef]

19. Hayasaka, H.; Noguchi, I.; Putra, E.I.; Yulianti, N.; Vadrevu, K. Peat fire-related air pollution in Central Kalimantan. Environ. Pollut. 2014, 195, 257-266. [CrossRef] [PubMed]

20. Lin, S.; Sun, P.; Huang, X. Can peat soil support a flaming wildfire? Int. J. Wildland Fire 2019, 28, 601-613. [CrossRef]

21. Usup, A.; Hashimoto, Y.; Takahashi, H.; Hayasaka, H. Combustion and thermal characteristics of peat fire in tropical peatland in Central Kalimantan, Indonesia. Tropics 2004, 14, 1-19. [CrossRef]

22. Huang, X.; Rein, G. Upward-and-downward spread of smoldering peat fire. Proc. Combust. Inst. 2019, 37, 4025-4033. [CrossRef]

23. Hayasaka, H.; Sepriando, A. 2015 severe peat fires and air pollution near the former mega rice project area in Central Kalimantan, Indonesia. In Proceedings of the 15th International Peat Congress 2016; Curran Associates: New York, NY, USA, 2015; pp. 323-326.

24. Wetlands International, Wageningen, The Netherlands. Available online: https://www.wetlands.org (accessed on 17 January 2020).

25. Pusat Database-BMKG. Jakarta, Indonesia. Available online: http://dataonline.bmkg.go.id/akses_data (accessed on 17 January 2020).

26. Japan Aerospace Exploration Agency. Tokyo: JAXA. Available online: https://sharaku.eorc.jaxa.jp/GSMaP/ index.html (accessed on 18 January 2020).

27. National Oceanic and Atmospheric Administration. Washington: NOAA. Available online: https://www. esrl.noaa.gov/psd/data/gridded/data.uninterp_OLR.html (accessed on 17 January 2020).

28. Liebmann, B.; Smith, C.A. Description of a Complete (Interpolated) Outgoing Longwave Radiation Dataset. Bull. Am. Meteorol. Soc. 1996, 77, 1275-1277.

29. National Oceanic and Atmospheric Administration. Washington: NOAA. Available online: https://www. esrl.noaa.gov/psd/data/gridded/data.interp_OLR.html (accessed on 17 January 2020).

30. Putra, E.I.; Hayasaka, H. The effect of the precipitation pattern of the dry season on peat fire occurrence in the Mega Rice Project area, Central Kalimantan, Indonesia. Tropics 2011, 19, 145-156. [CrossRef]

31. National Oceanic and Atmospheric Administration. Washington: NOAA. Available online: http://www.cpc. ncep.noaa.gov/data/indices (accessed on 17 January 2020).

32. Susilo, G.E.; Yamamoto, K.; Imai, T. Modeling groundwater level fluctuation in the tropical peatland areas under the effect of El Nino. Procedia Environ. Sci. 2013, 17, 119-128. [CrossRef]

33. Maréchal, J.C.; Dewandel, B.; Ahmed, S.; Galeazzi, L.; Zaidi, F.K. Combined estimation of specific yield and natural recharge in semi-arid groundwater basin with irrigated agriculture. J. Hydrol. 2006, 329, 281-293. [CrossRef]

34. Hayasaka, H. Predicting rainfall using outgoing longwave radiation (OLR) and peat fires in Indonesia. Hokkaido Branch J. Japan Meteorol. Soc. 2019, 65, 1-2. (In Japanese)

35. Hayasaka, H.; Takahashi, H.; Limin, S.H.; Yulianti, N.; Usup, A. Peat Fire Occurrence, chapter 25. In Tropical Peatland Ecosystems; Mitsuru, O., Nobuyuki, T., Eds.; Springer: Berlin/Heidelberg, Germany, 2016; pp. 377-395. ISBN 978-4-431-55681-7.

36. Babrauskas, V. Ignition Handbook; Fire Science Publishers: Issaquah, WA, USA, 2003.

(C) 2020 by the authors. Licensee MDPI, Basel, Switzerland. This article is an open access article distributed under the terms and conditions of the Creative Commons Attribution (CC BY) license (http://creativecommons.org/licenses/by/4.0/). 